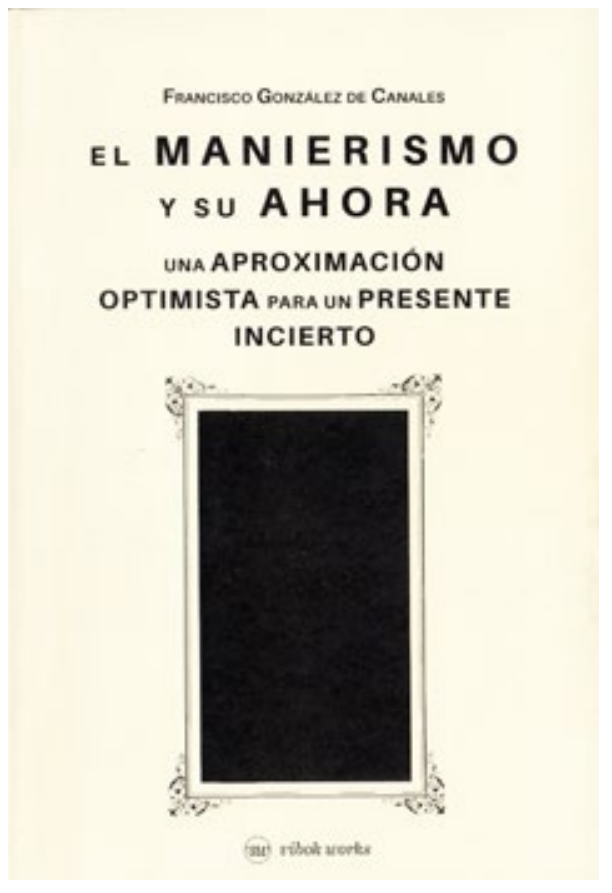

FRANCISCO GONZÁLEZ DE CANALES

El manierismo y su ahora: una aproximación optimista para un presente incierto

Sevilla, Vibok Works, 2020, 128 pp. Tapa blanda. $15 €$

Idioma: español

ISBN: 9788494646690

\section{RAÚL MARTÍNEZ MARTÍNEZ}

\section{Universitat Politècnica de Catalunya}

raul.martinez-martinez@upc.edu

En un contexto como el actual, donde relativismo y la sobreexposición informativa desorientan aún más a una sociedad falta de referentes y grandes relatos, se hace extremadamente difícil poder tener una visión global del estado de la arquitectura contemporánea. Dentro de este magma proclive a la confusión y al desasosiego, Francisco González de Canales nos propone a través del concepto de manierismo, un vector a partir del cual elaborar un discurso teórico que permita arrojar cierta luz a esta enmarañada situación. Ya en el proemio, el autor señala la recíproca relación que siempre ha existido entre la arquitectura y el momento histórico en el que ésta se produce, así que dentro de la realidad posmoderna en la que estamos imbuidos, la práctica arquitectónica formaliza esta condición presente que afecta al oficio de arquitecto.

Los capítulos-presente, manierismo, crisis, discusión-despliegan de forma gradual el argumento del libro: la percepción de una actitud manierista en la arquitectura reciente, ejemplificada en la obra de siete estudios de arquitectura europeos-Lütjens Padmanabhan (Zúrich), 6a Architects (Londres), Office KGDVS (Bruselas), TEd'A (Palma de Mallorca), Studio Wet (Sevilla), MAIO (Barcelona-Nueva York) y Andrés Jaque/Office for Political Innovation (Madrid-Nueva York)-. Este hecho permite a González de Canales mostrarnos el trabajo de una generación de arquitectos que, habiendo empezado su andadura profesional a inicios de este siglo, comparten una similar actitud para dar respuesta a los problemas que surgen en el quehacer arquitectónico diario. El tipo y la escala de los encargos en los que se ven imbuidos los protagonistas fomentan un cierto pragmatismo y ademán antiheroico en sus proyectos. Estos condicionantes y respuestas relacionadas con el presente inmediato sugieren al autor indagar sobre qué significa ser manierista hoy día, una aproximación que abre pie a la conjetura, pero también a la reflexión.

El relato propuesto se inicia con un recorrido histórico por los principales textos que han abordado el concepto de manierismo a lo largo del siglo XX, introduciendo al lector y al libro que tenemos entre manos, dentro de un ámbito de discusión teórica no menor que se ha dado en el campo de la historia del arte. La postura de González de Canales es claramente inclusiva y se suma a la visión diacrónica del manierismo que han adoptado historiadores de la arquitectura como Anthony Blunt o Colin Rowe. Dentro de esta genealogía, el historiador Arnold Hauser, con su vinculación del manierismo al concepto de crisis, y el arquitecto Robert Venturi, con su obra y su libro Complejidad y contradicción en la arquitectura, se convierten en referentes del texto. La mirada optimista a un presente inestable se consigue aceptando la crisis-el pensamiento del filósofo Edgar Morin es clave en esta acepción-así el manierismo, como actitud, es visto por el autor como el mecanismo capaz de trabajar con las propias complejidades del sistema, haciendo autocrítica desde dentro y suscitando posibles marcos de progreso al tensionar la realidad presente.

La discusión se desarrolla a partir del análisis formal de una serie de proyectos de pequeña escala en los que González de Canales pone el acento en aquellos rasgos que ejemplifican este talante manierista - la ambigüedad, la dualidad, lo equívoco, lo incierto, lo contradictorio-, algunas veces reconocido por los mismos arquitectos. El incisivo análisis morfológico de cada una de las obras seleccionadas permite al autor ahondar en el discurso teórico que se encuentra en el trasfondo de cada uno de estos estudios de arquitectura, exposición que se ve suplementada con referencias históricas - proporcionadas por el autor y/o los arquitectos - que ayudan a contextualizar las actuaciones y a reforzar el argumento. Las descripciones y comentarios provienen de la mirada de un arquitecto conocedor del oficio y la historia de la arquitectura, capaz de interpretar estas manipulaciones formales y hacernos ver esas cualidades manieristas implícitas en cada solución.

Pero esta reflexión formal no se limita al texto principal, sino que se traslada a la propia formalización del libro. El componente discursivo del texto se ve entrelazado con una acurada selección de imágenes relacionadas estrechamente con el contenido, entre las que se establece un diálogo visual - no en vano éstas vienen recogidas al final del libro bajo el título de "Citas visuales"- que incentiva a la comparación y el descubrimiento de nuevos significados. La carencia de un texto a pie de foto para cada una de las imágenes estimula esta lectura visual independiente del texto, experiencia que se complejiza con la inserción de unas breves notas en el lateral de la página para reforzar las ideas principales del pasaje. La superposición de todas estas capas da lugar a un volumen visualmente sugestivo que fomenta la confección de múltiples lecturas paralelas.

Este cuidado volumen es tanto un proyecto teórico, crítico, histórico como visual. La editora Paula V. Álvarez desarrolla esta última faceta del libro en un elaborado epílogo donde se ponen de relieve las cualidades e intenciones de un género literario como es el del ensayo editorial. Su texto nos permite contextualizar la propuesta de González de Canales situándola dentro de una tradición y un formato que se distingue por el carácter especulativo y abierto que comporta todo ensayo. La interacción entre la palabra y la imagen como mecanismo capaz de reforzar y enriquecer todo mensaje, es reivindicada por la autora, pero sus razonamientos van más allá del ámbito cultural alcanzando el estrato de la política. Así frente a la imperante 'estética de la desconexión', la editora defiende una 'estética de lo conectivo' término bajo el cual subyace una clara postura ética, social y política crítica con el sistema neoliberal.

En resumen, se trata de un libro que se estructura bajo la dualidad autor-editor, conteniendo dos textos que se enriquecen el uno al otro y que nos hacen recapacitar sobre el papel del arte y la arquitectura en la contemporaneidad. Sus contenidos son refrescantes y sugerentes. Éstos no sólo abren la puerta a reflexionar sobre los proyectos que son objeto de análisis e interesarnos por la filosofía y obra de los estudios de arquitectura implicados, sino que también incitan al lector a plantearse muchas cuestiones relacionadas con el presente inmediato: ¿cuál es la situación en la que se encuentra la práctica arquitectónica hoy día?, ¿cuál es el tipo de crisis en la que estamos imbuidos?, ¿cuál es la norma, doctrina o programa teórico que este posible manierismo intenta menoscabar?, ¿qué otros estudios de arquitectura mantienen una semejante actitud manierista?, etc.. El libro no ofrece respuestas claras a estas preguntas, pero lejos de ser una flaqueza, el incitar al lector a que proponga las suyas es sin duda una de sus grandes virtudes.

DOI: 10.26754/ojs_zarch/zarch.2021165599 